\title{
COWHIDE GELATIN NANOPARTICLES AND TITANIUM-PREPARED PLATELET-RICH FIBRIN POTENTIAL IN PERIODONTITIS HEALING PROCESS
}

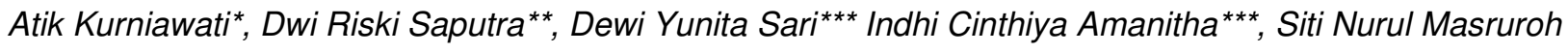 \\ Hariyati*** $^{* * 2}$ \\ *Bagian Biologi Oral Fakultas Kedokteran Gigi Universitas Negeri Jember \\ **Bagian Bedah Mulut dan Maksilofasial Fakultas Kedokteran Gigi Universitas Negeri Jember \\ *** Fakultas Kedokteran Gigi Universitas Negeri Jember \\ Correspondence : Bagian Biologi Oral Fakultas Kedokteran Gigi Universitas Negeri Jember \\ Email : atik.fkg@unej.ac.id
}

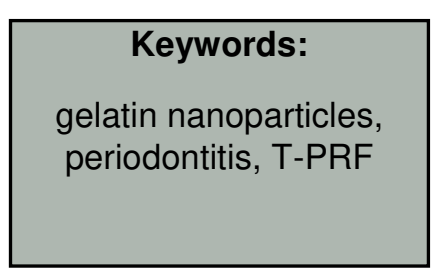

\begin{abstract}
Introduction: Based on epidemiological data, the periodontitis prevalence in Indonesia reached $96.58 \%$. Periodontitis is a periodontal disease caused by specific microorganisms causing attachment loss, alveolar bone resorption, and periodontal pocket. The pocket which is more than $6 \mathrm{~mm}$ couldn't be carried out using standard care. Therefore bone grafting is needed to fix the bone defect. Cowhide Gelatin nanoparticle (GNPs) combined with TitaniumPrepared Platelet-Rich Fibrin (T-PRF) is an innovative healing of periodontitis. Objective: To review the potential of cowhide gelatin nanoparticles combined with titanium-prepared platelet-rich fibrin (T-PRF) as an innovation in the healing of periodontitis defects.

Literature review: Cowhide GNPs are the main ingredients for the bone replacement, which are nano-sized, biocompatible, bioactive, osteoconductive, non-toxic, and have a porous structure that supports the drug-delivery process. T-PRF contains platelets, fibrin, growth factors that can stimulate bone regeneration.

Discussion: GNPs support the attachment and proliferation of osteoblast cells and the formation of mineralized bone matrix. The contents of T-PRF, which are fibrin, platelets, and growth factors, one of TGF- $\beta 1$ will produce bone formation and periodontal healing in the large number. Moreover, T-PRF has leukocyte-fibrin, which may give an antibacterial effect. Thus, GNPs combined with T-PRF have more potent properties that support each other in carrying out their functions to stimulate the healing process.

Conclusion: The combination of cowhide gelatin nanoparticles (GNPs) and titanium-prepared platelet-rich fibrin (T-PRF) has the potential to be effective in bone regeneration in periodontitis defects.
\end{abstract}

\section{INTRODUCTION}

Berdasarkan data epidemiologi, prevalensi periodontitis di Indonesia mencapai 96.58\%. Periodontitis kronis telah didefinisikan oleh American Academy of Periodontology (AAP) sebagai penyakit yang dihasilkan dari infeksi yang mengakibatkan inflamasi dalam jaringan penyangga gigi, kehilangan perlekatan yang progresif dan kehilangan tulang. ${ }^{1}$ Poket infraboni merupakan poket yang mengalami kerusakan tulang secara vertikal akibat proses inflamasi, serta tidak dapat diregenerasi secara fisiologis. Terapi poket infraboni dengan metode regenerasi jaringan yang menggunakan bahan graft, bertujuan untuk mengganti struktur tulang yang mengalami defek. Namun, kelemahan dalam terapi ini membutuhkan waktu yang lama dalam penyembuhannya, sehingga dibutuhkan suatu inovasi perawatan poket periodontal khususnya untuk mempercepat 
pembentukan tulang dan penyembuhan jaringan lunak. $^{2}$

Gelatin Nanoparticles (GNPs) kulit sapi merupakan suatu partikel nano polipeptida larut yang berasal dari kolagen bersifat biokompatibel, biodegradabel, bioaktif, osteokonduktif, osteoinduktif, injektabel, tidak bersifat toksik, high drug delivery, mendukung perlekatan dan proliferasi osteoblas, serta pembentukan matriks tulang yang termineralisasi. Dalam regenerasi tulang defek periodontitis, GNPs berperan sebagai scaffold. ${ }^{3,4}$ Namun GNPs memiliki beberapa kelemahan, yaitu kurangnya sifat mekanis dan respon biologis jika digunakan tanpa kombinasi apapun, sehingga potensi dalam regenerasi jaringan sangat terbatas. ${ }^{5}$ Transforming growth factor- $\beta 1$ (TGF- $\beta 1$ ) merupakan faktor pertumbuhan utama untuk regenerasi tulang serta penyembuhan luka, sehingga salah satu cara yang dapat ditempuh untuk membuat regenerasi tulang lebih efektif yaitu dengan peningkatan kadar TGF$\beta 1{ }^{6}$ Salah satu produk yang dapat meningkatkan kadar TGF- $\beta 1$ adalah platelet rich fibrin (PRF). PRF biasa digunakan dalam pencangkokan tulang (bonegrafting) untuk mempersingkat waktu penyembuhan luka dan memicu pembentukan matriks tulang. Salah satu jenis PRF yang biokompatibel dan memiliki kandungan-kandungan biologis yang memiliki kemampuan untuk memicu proses pembentukan tulang dan jaringan lunak adalah Titanium-Prepared Platelet-Rich Fibrin (TPRF). ${ }^{7}$

Titanium-prepared platelet-rich fibrin (T-PRF) merupakan salah satu jenis konsentrat trombosit yang memiliki kandungan growth factor, terutama TGF- $\beta 1$, yang melimpah. Selain itu, T-PRF memberikan sifat mekanis pada scaffold serta kaya akan platelet dan fibrin yang dapat mempercepat penyembuhan luka dan proses regenerasi tulang dan jaringan lunak. ${ }^{8,9}$

\section{TINJAUAN PUSTAKA}

Poket Periodontal pada Periodontitis

Periodontitis adalah proses inflamasi pada jaringan pendukung gigi yang disebabkan oleh mikroorganisme spesifik porphyromonas gingivalis, menyebabkan kerusakan ligamen periodontal dan tulang alveolar yang ditandai dengan pembentukan poket, resesi, maupun keduanya. Poket periodontal adalah pendalaman sulkus gingiva yang bersifat patologis. Poket periodontal merupakan gambaran klinis penyakit periodontal. ${ }^{1}$ Poket periodontal terjadi akibat kerusakan serabut kolagen ligamen periodontal dan diperiksa menggunakan probe periodontal. ${ }^{10}$ Poket periodontal dibagi menjadi 2, yaitu poket supraboni dan poket infraboni. Poket infraboni adalah poket dengan dasar poket terletak di apical puncak tulang alveolar. Dinding lateral poket terletak diantara permukaan gigi dan tulang alveolar. ${ }^{1}$

\section{Gelatin Nanoparticles (GNPs) Kulit Sapi}

Gelatin nanoparticles (GNPs) kulit sapi merupakan suatu partikel nano polipeptida larut yang berasal dari kolagen dimana merupakan suatu konstituen utama dari kulit, tulang, dan ligamen hewan. Gelatin diperoleh dari proses hidrolisis parsial kolagen. Ketika diberi asam atau basa disertai panas, maka struktur fibrosa kolagen dipecah secara irreversible dan menghasilkan gelatin. ${ }^{11}$ Sumber gelatin yang utama berasal dari kulit babi $(41 \%)$, kulit sapi $(28,6 \%)$, dan tulang $(30 \%)$. Keuntungan menggunakan gelatin kulit sapi yaitu kandungan protein yang sangat tinggi sekitar $84 \%-86 \%$, tetapi rendah kadar lemak. Gelatin yang bermutu tinggi diharapkan memiliki kandungan lemak yang rendah bahkan tidak mengandung lemak karena lemak menentukan mutu gelatin selama penyimpanan. ${ }^{12}$

Gelatin nanoparticles GNPs tidak larut tetapi dapat menyerap sejumlah besar air dibandingkan 
dengan jaringan polimer hidrofobik, misal poli (asam laktat), atau poli (asam laktat-asam glikolat). Kurangnya interaksi hidrofobik memungkinkan untuk enkapsulasi biomakromolekul yang umumnya larut dalam air. Rendahnya tingkat sitotoksisitas, biodegradabel, bioaktif, osteokonduktif, osteoinduktif, injectability dan biokompatibilitas sehingga GNPs adalah bahan yang menarik untuk menunjang drug delivery system. ${ }^{13}$ Saat ini, GNPs mulai digunakan dalam drug delivery system dan regenerasi jaringan karena dapat meningkatkan adhesi dan proliferasi sel, sehingga GNPs merupakan carrier system yang menjanjikan dalam sintesis partikel nano untuk drug delivery system yang terkontrol. ${ }^{14}$

Titanium-Prepared Platelet-Rich Fibrin (TPRF) merupakan modifikasi dari PRF dengan menggunakan titanium tube yang dibuat dari logam titanium grade IV. ${ }^{8,15}$ PRF adalah perancah fibrin yang padat yang terdiri dari matriks fibrin yang terpolimerisasi dan mengandung sitokin, trombosit, leukosit, dan sel punca yang bersirkulasi. ${ }^{16}$ Beberapa tindakan klinis dilaporkan berhasil menggunakan PRF, tapi beberapa dokter khawatir tentang kemungkinan health hazard pada dry glass yang mengandung aktivator silika, ${ }^{9,17,18}$ meskipun silika tersebut dibutuhkan untuk pembentukan agregasi platelet dan fibrin pada PRF namun disisi lain partikel silika dapat mengkontaminasi berbagai pengobatan pada pasien. ${ }^{18}$

Titanium yang digunakan dalam pembuatan $\mathrm{T}$ PRF merupakan salah satu logam dengan rasio strength-to-weight yang tinggi dan resisten terhadap korosi sehingga memiliki biokompatibilitas yang sangat baik untuk berkontak dengan darah (sifat hemo-kompatibilitas). Hemo-kompatibilitas dari titanium dapat mempengaruhi pembentukan lebih banyak polimerisasi fibrin secara potensial. Titanium menginduksi agregasi platelet mirip dengan glass tube, dan menghasilkan clot yang secara klinis identik dengan yang dihasilkan oleh glass tube. ${ }^{17}$ Fibrin carpet yang dibentuk dengan titanium memiliki struktur yang lebih rapat dibandingkan glass tube dan masa resorpsi di jaringan jauh lebih lama, kira-kira selama 1 bulan, waktu yang cukup untuk memulai pembentukan tulang baru. 8,18,19 Material ini juga digunakan untuk menghindari berbagai efek negatif jangka panjang maupun pendek dari dry glass. ${ }^{18}$ Sama halnya dengan PRF, T-PRF juga mengandung komponen biologis yang berperan penting dalam proses pembentukan tulang dan penyembuhan luka pasca pembedahan. Komponen tersebut yaitu faktorfaktor pertumbuhan, dengan konsentrasi yang tinggi diantaranya fibroblast growth factors-2 (FGF2), platelet derived growth factors (PDGFs), dan transforming growth factor $\beta 1$ (TGF- $\beta 1$ ). ${ }^{10}$

\section{Regenerasi tulang}

Regenerasi tulang adalah proses pembentukan tulang yang kompleks, terkoordinasi dengan baik dan tidak berbeda dengan tulang aslinya. Mekanisme proses regenerasi tidak terlepas dari prinsip rekayasa jaringan atau tissue engineering yaitu adanya sel, scaffold (graft dan PRF), dan growth factor. ${ }^{20}$

Proses regenerasi tulang terjadi dalam beberapa tahap, diawali dengan pembentukan dan aktivasi dari sel osteoklas, setelah itu akan dilanjutkan dengan proses resorbsi matriks serta mineral tulang oleh sel osteoklas, kemudian memasuki tahap dari osteoklas ke osteoblas. Pada tahap ini sel osteoklas akan menghilang dan rongga bekas resorbsi diisi oleh sel berinti tunggal yang diduga sebagai sel prekursor osteoblas yang selanjutnya berkembang menjadi osteoblas. Sebagian dari osteoblas yang matang akan membentuk matriks tulang dan menetap sebagai osteosit, sementara beberapa osteoblas lainnya 
akan mati dan sebagian berubah menjadi bone lining cell. ${ }^{20}$

\section{PEMBAHASAN}

Faktor terpenting dalam proses penyembuhan luka adalah terjadinya proses angiogenesis yang mengirimkan nutrisi dan sel sel inflamasi. Pada fase remodeling dan fase maturasi, sitokin yang menstimulus terjadinya angiogenesis terhenti, dan berakibat terjadinya kemunduran pembentukan tabung tabung kapiler. Oleh karena itu, diperlukan bahan aktif yang mampu memicu pertumbuhan tulang dan penyembuhan luka pada sisi pembedahan. ${ }^{21}$

Pembentukan tulang adalah sebuah proses kompleks yang dimulai dengan perekrutan sel-sel osteoprogenitor yang kemudian terdiferensiasi menjadi osteoblas, dengan selanjutnya pembentukan osteoid dan mineralisasi matriks. ${ }^{22}$ Pada proses penyembuhan, pembentukan tulang woven dimulai dengan penetrasi sel mesenchymal yang tidak terdiferensiasi yang berdiferensiasi menjadi generasi osteogenik. Kemudian terbentuklah proyeksi seperti jari (finger-like projection) dari jaringan yang termineralisasi. Proyeksi seperti jari yang teridentifikasi tersebut mengelilingi pembuluh darah dan memunculkan formasi sistem Harvesian yang sesekali diperkuat oleh tulang yang berserat paralel..$^{23}$

Terdapat beberapa faktor-faktor pertumbuhan yang telah dibuktikan muncul pada tahap awal dan menengah proses pembentukan tulang dan aktivasi osteogenesis. Faktor-faktor pertumbuhan tersebut meliputi platelet derived growth factor (PDGF), vascular endothelial growth factor (VEGF), bone morphogenetic proteins (BMPs), insuline like gowth factor (IGF), transforming growth factor $\beta$ (TGF $\beta$ ), dan fibroblast growth factor (FGF). Faktor faktor tersebut memiliki peranan penting dalam proses pembentukan tulang. ${ }^{23}$

Perancah atau scaffold seringkali dibutuhkan untuk untuk menduplikasi lingkungan mikro in vivo/ekstraseluler matriks ekstraseluler (ECM) pada proses akselerasi pembentukan tulang. Penggunaan perancah juga bertujuan untuk mendukung proses proliferasi, diferensiasi, serta maturasi dari sel-sel. ${ }^{24}$ Dalam hal menduplikasi lingkungan mikro sebagai media migrasi dan adhesi sel, struktur fiber dalam Platelet Rich Fibrin (PRF) juga dapat membuat struktur jaringan fibrin yang tebal dan fleksibel sehingga terbukti mampu menciptakan lingkungan yang kondusif untuk memicu terjadinya proses pembentukan jaringan tulang baru. Jaringan fibrin yang tebal dan fleksibel tersebut sangat menguntungkan bagi migrasi selsel osteogenik dan juga berperan sebagai penangkap mokelul sitokin. Ketika matriks fibrin PRF mengalami remodeling, sitokin dilepaskan secara bertahap. Dengan begitu dapat dipastikan bahwa faktor-faktor pertumbuhan akan terus dilepaskan sehingga hal tersebut dapat memicu proliferasi sel selama proses pembentukan tulang. 7,17

Gelatin nanoparticles merupakan scaffold yang berasal dari fragmen protein yang diperoleh dari degradasi kolagen parsial serat. ${ }^{24}$ nano gelatin memiliki banyak keuntungan yakni biokompatibilitas, antigenisitas rendah, biodegradabilitas, hydrogel, dan tersedia dengan biaya rendah, serta telah digunakan luas dalam rekayasa jaringan. Kehadiran motif pengenalan integrin Arg -Gly-Asp (RGD) dalam gelatin juga mendukung adhesi sel (stem cells).24,25

Peptida yang mengandung urutan argininglisin-aspartat (RGD) merupakan protein adhesi dalam matriks ekstraseluler yang memiliki peranan penting. Oleh karena itu, RGD telah banyak digunakan dalam modifikasi biomaterial dan pola 
RGD juga telah digunakan untuk studi dasar interaksi sel dengan scaffold pada tissue engineering. ${ }^{26}$ Adhesi sel terhadap scaffold pada RGD terjadi ketika adanya interaksi arginin-glisinaspartat (RGD), yang dapat secara spesifik terikat ke integrin ( $\alpha$-chain dan $\beta$-chain) reseptor dengan melintasi membran. Adanya keterikatan antara stem cells dan matriks ekstraseluler akan dilanjutkan dengan terjadinya tranduksi sinyal dari stem cell menuju matriks ekstraseluler. ${ }^{24,26,27} \mathrm{Hal}$ inilah yang mendasari proses adhesi, diferensiasi, dan maturasi stem cells. ${ }^{27}$

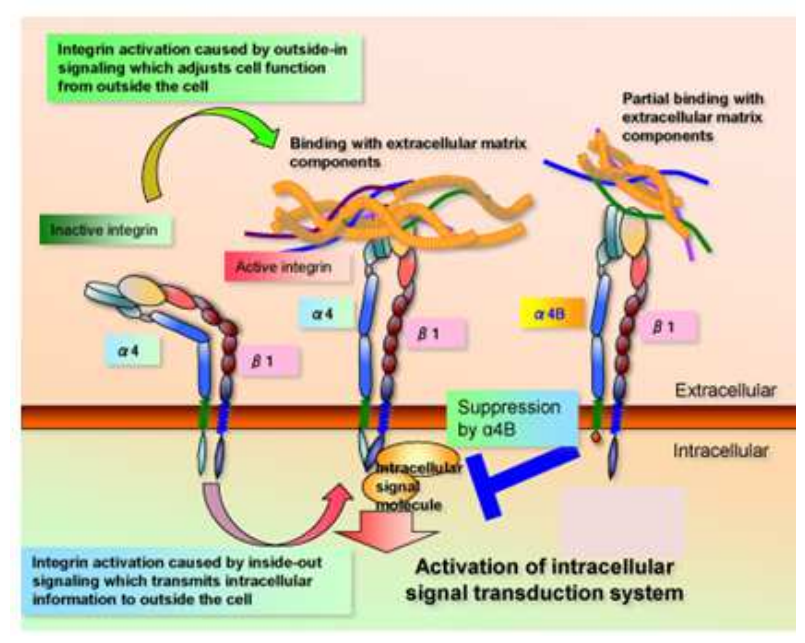

Gambar 1. Mekanisme adhesi RGD-integrin ${ }^{28}$

Transforming growth factor $\beta 1$ (TGF- $\beta 1$ ) memiliki peranan utama dalam proses regenerasi jaringan tulang, yaitu dengan meningkatkan proliferasi osteoblas dan produksi matriks osteoblas, melalui daya tarik kemotaktik, dan meningkatkan produksi protein matriks ekstraseluler oleh osteoblas dalam tahap awal diferensiasi osteoblas. ${ }^{29}$ Telah ditunjukkan bahwa konsentrasi TGF- $\beta$ yang tinggi akan menurunkan pelepasan receptor activator of nuclear factor kappa $B$ ligand, sedangkan konsentrasi rendah meningkatkan pematangan osteoklas. Selain itu TGF- $\beta$ juga menginduksi ekspresi kolagen tipe 1 dan gen penanda osteogenik pada mesenchymal stemcells (MSCs). ${ }^{30}$ Transforming growth factor 1 - $\beta$ (TGF 1- $\beta$ ) yang berperan penting dalam akselerasi pembentukan tulang dan penyembuhan luka pasca pembedahan. Transforming growth factor 1- $\beta$ (TGF 1- $\beta$ ) memicu pembentukan tulang baru melalui stimulasi pembentukan komponen yang sangat penting pada tulang, yakni kolagen dan fibronektin. Fibronektin dapat meningkatkan adesi dan migrasi sel. Sel yang dapat beradhesi dengan fibronektin yakni sel osteoblas yang berperan penting dalam proses pembentukan tulang. ${ }^{7,17}$

Transforming growth factor $\beta 1$ (TGF- $\beta 1$ ) juga dapat bekerja sama dengan bone morphogenetic protein 1 (BMP 1) untuk mengatur diferensiasi osteoblas. Kebanyakan BMP mengaktifkan Smad1 /5/8 sebagai R-Smad. Kompleks Smad1/5/8 Smad4 mentranskripsi ekspresi Runx2 untuk memulai ekspresi gen osteoblas lainnya. ${ }^{31}$ Pada fase awal diferensiasi osteoblastik (diferensiasi MSCs ke sel-sel progenitor osteoblas), Runtrelated transcription factor 2 (Runx2) atau corebinding factor subunit alpha-1 (Cbfa1), yang merupakan faktor transkripsi utama dalam pembentukan tulang, menghambat diferensiasi MSCs ke jenis sel selain osteoblas. Mekanisme penghambatan diferensiasi tersebut membutuhkan tindakan terkoordinasi antara Runx2 dan BMP-2 yang diinduksi oleh protein coding SMAD member 5 (Smad5). Pada fase kedua yaitu diferensiasi selsel progenitor osteoblas ke osteoblas, TGF- $\beta 1$ menginduksi pelepasan dari Runx2 untuk mendorong diferensiasi. Namun, pada tahap diferensiasi akhir osteoblas, TGF- $\beta 1$ menentang aksi BMP-2. Smad3 diaktifkan oleh TGF- $\beta 1$, berinteraksi secara fisik dengan Runx2 dan menekan ekspresi Runx2. Runx2 mencegah diferensiasi osteoblas dewasa menjadi osteosit, dan mempertahankannya dalam keadaan istirahat. Dengan demikian, TGF- $\beta 1$ dapat mempromosikan pengembangan osteosit dengan menurunkan 
regulasi Runx2 pada osteoblas dewasa. Hal ini menunjukkan bahwa TGF- $\beta 1$ dapat menyelaraskan diferensiasi osteoblas. ${ }^{29}$

Konsentrasi transforming growth factor $\beta 1$ TGF- $\beta 1$ dengan konsentrasi tinggi dapat mengatur ekspresi dan sekresi osteoprotegerin (OPG) dan mengatur regulasi receptor and activator of nuclear factor $k B$ ligand (RANKL) oleh osteoblas. Keseimbangan RANKL dan OPG sangat penting untuk pembentukan dan aktivitas osteoklas. Karena pengikatan ligan (RANKL) ke receptor and activator of nuclear factor $k B$ (RANK) mendorong sel-sel prekursor untuk berdiferensiasi menjadi osteoklas lineage. Interaksi tersebut meningkatkan pembentukan dan aktivitas osteoklas. OPG adalah umpan yang dapat berikatan dengan reseptor dan menjadi pesaing RANKL dalam ikatannya dengan RANK dan dengan demikian dapat menghambat osteoklastogenesis. Dengan demikian, konsentrasi tinggi TGF- $\beta 1$, yang diinduksi oleh T-PRF, dapat meningkatkan pembentukan tulang dan menurunkan resorbsi tulang. ${ }^{29,32}$

Gelatin nanoparticles (GNPs) merupakan scaffold yang dapat digunakan dalam perbaikan kerusakan tulang periodontal. GNPs bersifat biokompatibel, biodegradabilitas, bioaktif, osteokonduktif, injectability, non-toxic, dan high drug delivery sehingga mendukung perlekatan dan proliferasi osteoblas serta pembentukan matriks tulang yang termineralisasi. Peran GNPs sebagai scaffold yang menyediakan lingkungan mikro tiga dimensi fisikokimia dan biologis untuk pertumbuhan dan diferensiasi sel, mempromosikan adhesi sel, dan migrasi sel. GNPs juga berfungsi sebagai transportasi nutrisi, oksigen, dan limbah metabolisme sel. ${ }^{24}$

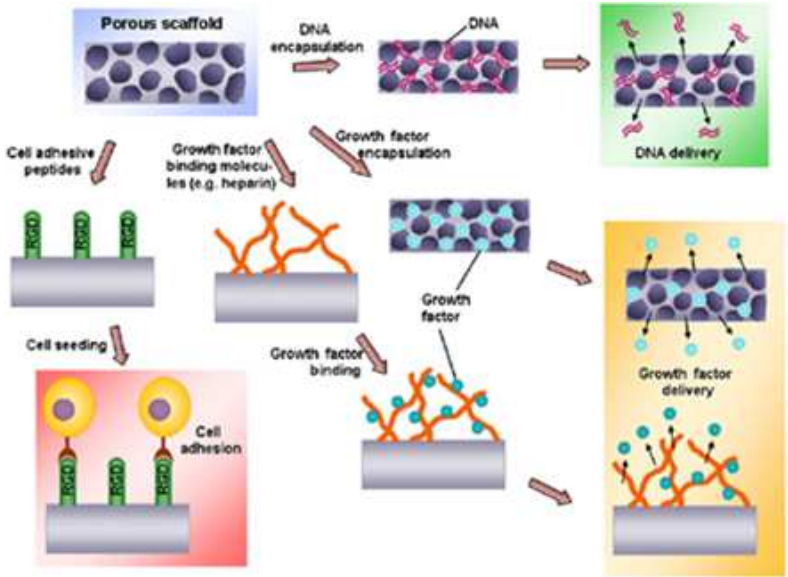

Gambar 2. Struktur porous scaffold menunjang dalam cell adhesion, growth factor binding, growth factor encapsulation, dan DNA encapsulation untuk meningkatkan proliferasi dan morfogenesis sel. ${ }^{33}$

Stem cells dapat melekat pada gelatin nanoparticles GNPs sebelum berdiferensiasi menjadi osteoblas untuk membentuk matriks tulang. ${ }^{34}$ Di sisi lain, kandungan kolagen tipe 1 pada GNPs memungkinkan terjadinya pengaturan preosteotoblas dan mengikat osteoblas yang baru untuk mendukung kerangka osteogenesis. Fibronektin memediasi pengikatan molekul pensinyalan dan memainkan peran dalam interaksi antara matriks ekstraseluler dan sel untuk mengatur ulang sitoskeleton polarisasi pre-osteotoblas pada proses regenerasi tulang. GNPs akan terdegradasi secara bertahap dan diganti oleh jaringan regeneratif. ${ }^{34}$ Oleh karena itu, dibutuhkan scaffold tambahan yang dapat memacu regenerasi tulang dan memacu kerja GNPs, yaitu titanium-prepared platelet rich fibrin (T-PRF). Scaffold yang dapat digunakan untuk memberikan sifat osteoinduktif dengan menyuplai faktor faktor pertumbuhan pada lokasi tulang yang rusak untuk mempercepat terjadinya regenerasi tulang. ${ }^{35}$

Titanium-prepared platelet rich fibrin (T-PRF) merupakan modifikasi dari platelet rich fibrin (PRF) dengan menggunakan tabung titanium yang dibuat dari logam titanium grade IV yang memiliki sifat 
hemokompatibilitas. Sifat ini yang menyebabkan TPRF dapat bertahan pada jaringan lebih lama. Selain itu, T- PRF juga kaya akan fibrin dan faktorfaktor pertumbuhan. Faktor-faktor pertumbuhan tersebut mendukung proses regenerasi jaringan lunak maupun keras, terutama untuk penyembuhan/regenerasi tulang. ${ }^{8,9}$ Transforming growth factor $\beta 1$ (TGF- $\beta 1$ ) merupakan faktor pertumbuhan utama dalam regenerasi tulang. TGF$\beta 1$ berperan dalam meningkatkan proliferasi osteoblas dan juga osteoblas prekursor atau produksi matriks osteoblas ke daerah yang memerlukan melalui daya tarik kemotaktik. TGF- $\beta 1$ juga berperan sebagai penekan proliferasi dari prekursor osteoklas. Semakin tinggi konsentrasi TGF- $\beta 1$, maka proses regenerasi semakin baik karena diferensiasi osteoklas yang menurun, sedangkan diferensiasi osteoblas meningkat. ${ }^{29}$

Sinergik antara berbagai kandungan titaniumprepared platelet rich fibrin (T-PRF), terutama TGFB1 dan bone morphogenetic (BMP) dapat menunjang regenerasi tulang, karena diferensiasi mesenchymal stem cells (MSCs) terarahkan menjadi sel osteoblas. ${ }^{29}$ Proliferasi, maturasi, dan diferensiasi yang dihasilkan oleh T-PRF serta kombinasi dengan gelatin nanoparticles (GNPs) kulit sapi berpotensi dalam penyembuhan kerusakan tulang pada periodontitis.

\section{KESIMPULAN}

Rekayasa jaringan merupakan perawatan yang menjanjikan sebagai alternatif transplantasi tulang khususnya pada perawatan periodontitis. Gelatin nanoparticles (GNPs) dapat digunakan sebagai scaffold potensial karena minimnya respons imun tubuh, tingginya biokompatibilitas. Kombinasi GNPs dengan titanium-prepared platelet rich fibrin (T-PRF) berpotensi sebagai agen penyembuhan kerusakan tulang pada periodontitis dengan meningkatkan transforming growth factor $\beta 1$ (TGF- $\beta 1$ ) yang dapat memacu proliferasi, diferensiasi, dan maturasi sel osteoblas, fibroblas, dan beberapa jenis sel mesenkimal, serta memungkinkan kolonisasi sel osteoblas sehingga terjadi proses mineralisasi dan pembentukan tulang secara efektif.

\section{DAFTAR PUSTAKA}

1. Newman MG, Takei, HH, Klokkevold, PR. Carranza's Clinical Periodontology. 2012. California: Elsevier.

2. Kubota T., Nemoto Y., Nohno K., et al. $A$ Comparable Study of Combinational Regenerative Therapies Comprising Enamel Matrix Derivative plus Deproteinized Bovine Bone Mineral with or without Collagen Membrane in Periodontitis Patients with Intrabony Defects. Open Journal of Stomatology 2018; 8(09): 277.

3. Elzoghby, A.O. Gelatin-based nanoparticles as drug and gene delivery systems: reviewing three decades of research. Journal of Controlled Release 2013; 172(3): 1075-1091.

4. Bakopoulou, A., Georgopoulou, A., Grivas, I., et al. Dental pulp stem cells in chitosan/gelatin scaffolds for enhanced orofacial bone regeneration. Dental Materials 2019; 35(2): 310-327.

5. Shin JY, Jeong SJ, Lee WK. Fabrication of porous scaffold by ternary combination of chitosan, gelatin, and calcium phosphate for tissue engineering. Journal of Industrial and Engineering Chemistry 2019; 80: 9862.

6. Chen G, Deng C, Li YP. TGF- $\beta$ and BMP signaling in osteoblast differentiation and bone formation. International journal of biological sciences 2012; 8(2):272.

7. Atalay B, Doganay, O. The Use of PlateletRich Fibrin in Bone Grafting. Bone Grafting 2018; 7: 95-102.

8. Ozdemir $\mathrm{H}$, Ezirganli S, Kara MI, et al. Effects of platelet rich fibrin alone used with rigid titanium barrier. Archives of oral biology 2013; 58(5): 44-537.

9. Arabaci T, Albayrak M. Titanium-prepared platelet-rich fibrin provides advantages on periodontal healing: A randomized splitmouth clinical study. Journal of periodontology 2018; 89(3): 64-255.

10. Preshaw PM, Alba AL, dan Herrera. Periodontitis And Diabetes: A Two Way Relationship Review. J Diabetalogia 2012; 55: 21-31. 
11. Kurniawan F, Nugroho A. Deteksi Gelatin Babi Menggunakan Sensor Emas Termodifikasi NiO Nanopartikel pada Quartz Crystal Microbalance. Jurnal Sains dan Seni ITS 2015; 4(2).

12. An SM, Kim MJ, Seong KY, et al. Intracutaneous Delivery of Gelatins Reduces Fat Accumulation in Subcutaneous Adipose Tissue. Toxicological research 2019; 35(4): 395.

13. Jaipan P, Nguyen A, Narayan RJ. Gelatinbased hydrogels for biomedical applications. MRS Communications 2017; 7(3): 26-416.

14. Chen S, Zhang $Q$, Nakamoto $T$, et al. Gelatin scaffolds with controlled pore structure and mechanical property for cartilage tissue engineering. Tissue Engineering Part C: Methods 2016; 22(3): 98-189.

15. Olgun E, Ozkan SY, Atmaca HT, et al. Comparison of the clinical, radiographic, and histological effects of titaniumprepared platelet rich fibrin to allograft materials in sinus-lifting procedures. Journal of investigative and clinical dentistry. 2018; 9(4): e12347.

16. Liu Y, Sun X, Yu J, Wang J, et al. Platelet Rich Fibrin as a Bone Graft Material in Oral and Maxillofacial Bone Regeneration: Classification and Summary for Better Application. BioMed Research International 2019; 2019: 1-11.

17. Tunalı $M$, Özdemir $H$, Küçükodacı $Z$, et al. A novel platelet concentrate: titaniumprepared platelet-rich fibrin. BioMed research international. 2014; 2014.

18. Tunali M, Ozdemir H, Kucukodacı Z, et al. A novel platelet concentrate for guided bone regeneration: Titanium Prepared Platelet-Rich Fibrin (T-PRF). Gulhane Med J 2015; 57: 6-102.

19. Ustaoğlu G, Ercan E, Tunali M. The role of titanium-prepared platelet-rich fibrin in palatal mucosal wound healing and histoconduction. Acta Odontologica Scandinavica 2016; 74(7): 64-558.

20. Widyawati, SD. Pengaruh Pemberian Platelet Rich Fibrin dan Deproteinized Porous Bovine Bone Terhadap Aktivitas Transforming Growth Factor- $\beta 1$ Dan Konsentrasi Osteokalsin. Skripsi 2014. Jakarta: Fakultas Kedokteran Gigi.

21. Pellegrini G, Farronato D, Rasperini G, et al. Soft Tissue Healing in Alveolar Socket Preservation Technique: Histologic Evaluations. The international journal of periodontics \& restorative dentistry 2014; 34(4): 537.
22. Efremov L, Bosnakovski D, Kanjevac T. Perspectives on regeneration of alveolar bone defects. Ser J Exp Clin Res 2013; 14(4): 145-153.

23. Gomes PS, Daugela P, Poskevicius L et al. Molecular and Cellular Aspects of Socket Healing in the Absence and Presence of Graft Materials and Autologous Platelet Concentrates: a Focused Review. J Oral Maxillo Fac Res 2019; 10(3): p1-p18.

24. Deidda G, Jonnalagadda SV, Spies JW, et al. Self-assembled amyloid peptides with Arg-Gly-Asp (RGD) motifs as scaffolds for tissue engineering. ACS Biomaterials Science \& Engineering 2017; 3(7): 161404.

25. Meng ZX, Wang YS, Ma C, et al. Electrospinning of PLGA/gelatin randomlyoriented and aligned nanofibers as potential scaffold in tissue engineering. Materials Science and Engineering: $C$ 2010; 30(8): 10-1204.

26. Ahn CB, Kim Y, Park SJ, et al. Development of arginine-glycine-aspartateimmobilized 3D printed poly (propylene fumarate) scaffolds for cartilage tissue engineering. Journal of Biomaterials Science, Polymer edition 2018; 29(7-9): 31917.

27. Elzoghby AO. Gelatin-based nanoparticles as drug and gene delivery systems: reviewing three decades of research. Journal of Controlled Release 2013; 172(3): 91-1075.

28. Kouro $\mathrm{H}$, Kon $\mathrm{S}$, Matsumoto $\mathrm{N}$, et al. The novel $\alpha 4 B$ murine a4 integrin protein splicing variant inhibits a4 proteindependent cell adhesion. Journal of Biological Chemistry 2014; 289(23):9816389.

29. Kasagi S, Chen W. TGF-beta1 on osteoimmunology and the bone component cells. Cell \& Bioscience 2013; 3(1): 4.

30. Glueck M, Gardner O, Czekanska E, et al. Induction of osteogenic differentiation in human mesenchymal stem cells by crosstalk with osteoblasts. BioResearch open access 2015; 4(1): 30-121

31. Wu M, Chen G, Li YP. TGF- $\beta$ and BMP signaling in osteoblast, skeletal development, and bone formation, homeostasis and disease. Bone research 2016; 4: 16009.

32. Rahman, MS., Akhtar, N., Jamil HM., et al. TGF-B/BMP signaling and other molecular events: regulation of osteoblastogenesis and bone formation. Bone research 2015; 3: 15005.

33. Pillay V, Kumar P, Choonara YE, et al. Processing and Templating of Bioactive- 
Loaded Polymeric Neural Architectures: Challenges and Innovative Strategies. Recent Advances in Novel Drug Carrier Systems. InTech Publishers; 2012 :92-355.

34. Bakopoulou A, Georgopoulou A, Grivas I, et al. Dental pulp stem cells in chitosan/gelatin scaffolds for enhanced orofacial bone regeneration. Dental Materials 2019; 35(2): 27-310.
35. Yu Q, Han FJ, Lv DS. To compare the healing of pressure sores by the use of combination therapy with platelet rich plasma and gelatin hydrogel versus platelet rich plasma and collagen. Biomedical Research 2017; 28(3): 12-22 